\title{
A SHOOTING EXPERIMENT WITH RECONSTRUCTED SCYTHIAN ARROWS AND BOWS \\ New Data on the Iron Age Siege at Dédestapolcsány-Verebce-tető
}

\author{
Gábor V. Szabó ${ }^{1}$ - Attilla Kiss ${ }^{2}$ - Zoltán Henrik Tóth ${ }^{3}$ \\ Hungarian Archaeology Vol. 10 (2021), Issue 3, pp. 43-52. https://doi.org/10.36338/ha.2021.3.5
}

The archaeological research of the last decades revealed that around the beginning of the Middle Iron Age, in the middle of the 7th century BC, the territory of Northeast Hungary and Western Slovakia and the eastern part of today's Czech Republic were hit by an extensive series of attacks. Approximately 20 fortified settlements are known today where bronze arrowheads, found along pristine hillfort walls, bear witness to devastating sieges that occurred almost simultaneously. ${ }^{4}$

The most spectacular evidence of the Early Iron Age attack series in the territory of Hungary is the fortified settlement at Dédestapolcsány-Verebce-tetö, located at the fringes of the Bükk Mountains. Hundreds of early Scythian-type cast bronze arrowheads have been discovered there, scattered along the northern wall of the defensive earthworks surrounding the inhabitation zone.

Recently, as part of a new research project, we have conducted a shooting experiment using reconstructed Scythian-type bows and arrows to obtain additional information about the efficiency of the bows and arrows used in the siege, as well as about the probable progress and details of the event.

Keywords: archery, early Scythian arrowheads, experimental archaeology, Iron Age, siege

\section{THE ARCHAEOLOGICAL EVIDENCE RELATED TO THE SIEGE}

In a previous volume of Hungarian Archaeology, we have published a summary of the metal detector aided survey campaign conducted in 2011, in the course of which we have discovered hundreds of early Scythian-type arrowheads in the northern zone of the prehistoric settlement at Dédestapolcsány-Verebce-tető, an Early Iron Age hillfort with a terraced inhabitation area surrounded by large defensive earthworks (V. Szabó, Czajlik \& Reményi 2014; V. Szabó 2018). Almost 300 specimens, representing the majority of the arrowheads, scattered in a relatively small patch of about forty to fifty metres in length by the ramparts protecting the southern gate of the settlement. Following field campaigns revealed that arrowheads may also be found in other parts of the site: in $2016^{5}$ and 2020, systematic examinations of the previously

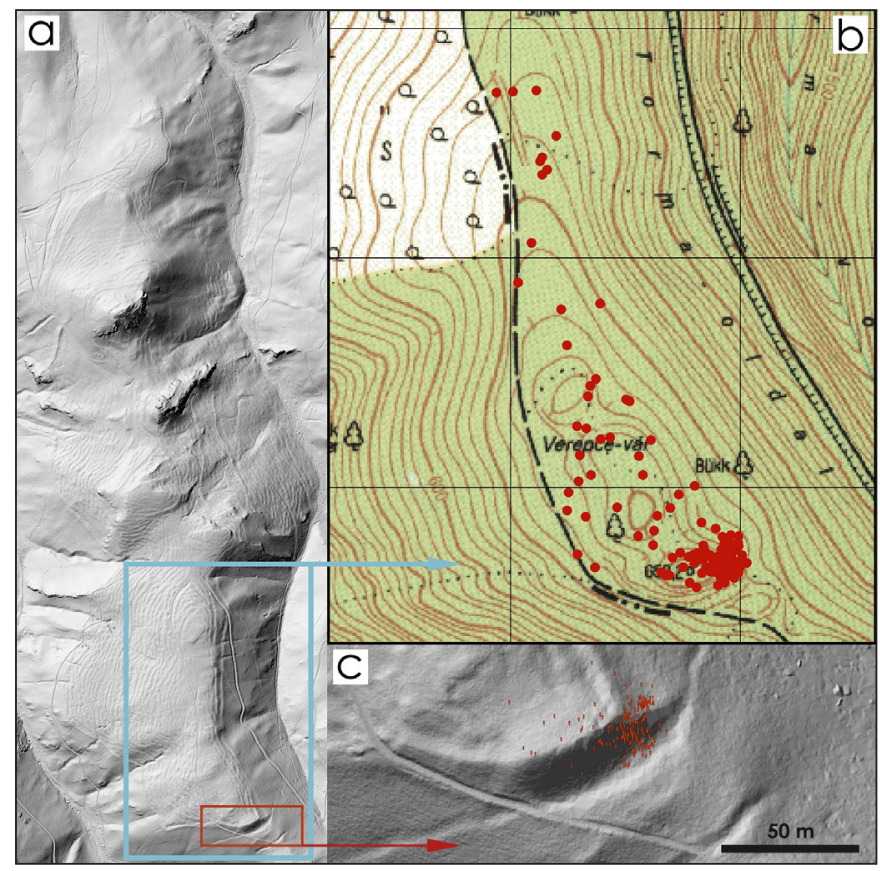

Fig. 1. a) LiDAR survey of Dédestapolcsány-Verebce-bérc; b) findspots of the arrowheads collected in 2018 in the settlement area close to the southern ramparts; c) findspots of the arrowheads discovered in 2011 in the area of the southern ramparts

\footnotetext{
ELTE Faculty of Humanity, Institute of Archaeological Sciences. E-mail: vasagab@gmail.com

“Zengő Nyíl” Historical Archery School. E-mail: kiss0702@,freemail.hu

Hungarian Historical Archery Society. E-mail: tzhenator@gmail.com

4 The siege horizon was outlined in Chochorowski 2014, 32-43, Abb.19, 24; Hellmuth-Kramberger 2017, 584; NovÁk 2017, 197-206, Fig. 9; and KLÁPA 2017.

5 We are grateful to István Bacskai and Marianna Bálint for sharing the results of the surveys conducted in 2016 with us.
} 
barely explored settlement area yielded 62 more arrowheads (Fig. 1). The distance between the core of the find concentration by the southern ramparts and the arrowhead discovered farthest away from that is 540 metres. Besides arrowheads, the surveys of the settlement area also provided us with several intact objects from the Early Iron Age (e.g., boat-shaped brooches, or Kahnfibeln, a zoomorphic bronze pendant, a multi-headed decorative pin, or Mehrkopfnadel) as well as many burnt and fragmented ones.

The available archaeological information has allowed us to reconstruct some details of the siege. The archers attacked the settlement where it was the easiest to approach: in the southeastern corner, at an earthwork section with a bastion or some other kind of shooting station on top. A group of archers probably lined up along the narrow road before the gate to keep the defenders of the bastion under concentrated fire, while another group was attempting to pass through the defensive earthwork elsewhere. The majority of the arrowheads were chipped or broken, suggesting that the fired arrows had hit a solid surface with great power.

Preliminary typological evaluation of the arrowheads recovered from the territory of Dédestapolcsány revealed that the types were used mainly in the second half of the 7th century BC by communities of forest-steppe origin occupying, at the time, the territory of Transylvania around the upper course of the Maros, and the forest-steppe zone east of the Carpathian Mountains, along the middle course of the Dniestr. These communities appear in the era's archaeological record through cemeteries with burials fitted with weapon, attire element, and horse harness types characteristic to their area of origin (V. SzABÓ, CzAJLIK \& REMÉNYI 2014, 6; Hellmuth-Kramberger 2017, 576-577).

\section{UNKNOWN DETAILS OF THE SIEGE: THE QUESTIONS OF THE SHOOTING EXPERIMENT}

By conducting a shooting experiment with replica bows and arrows, we were seeking answers to multiple questions.

First, how far did the attackers stand from the walls? A systematic investigation of the area before the ramparts did not yield any archaeological evidence about their positions.

Second, how far did the fired arrows fly? What was the deepest point inside the settlement an arrow, fired from outside of the ramparts, could have reached? Do the arrowheads discovered far from the earthworks in the settlement area represent evidence that the attackers breached the walls and got into the inhabitation zone?

Third, what materials did the arrows hit, and what caused the deformations of the arrowheads? Many of them were bent or broken, and molten ones were also found (Fig. 2), suggesting perhaps that the attackers tried to set the ramparts on fire during the siege.

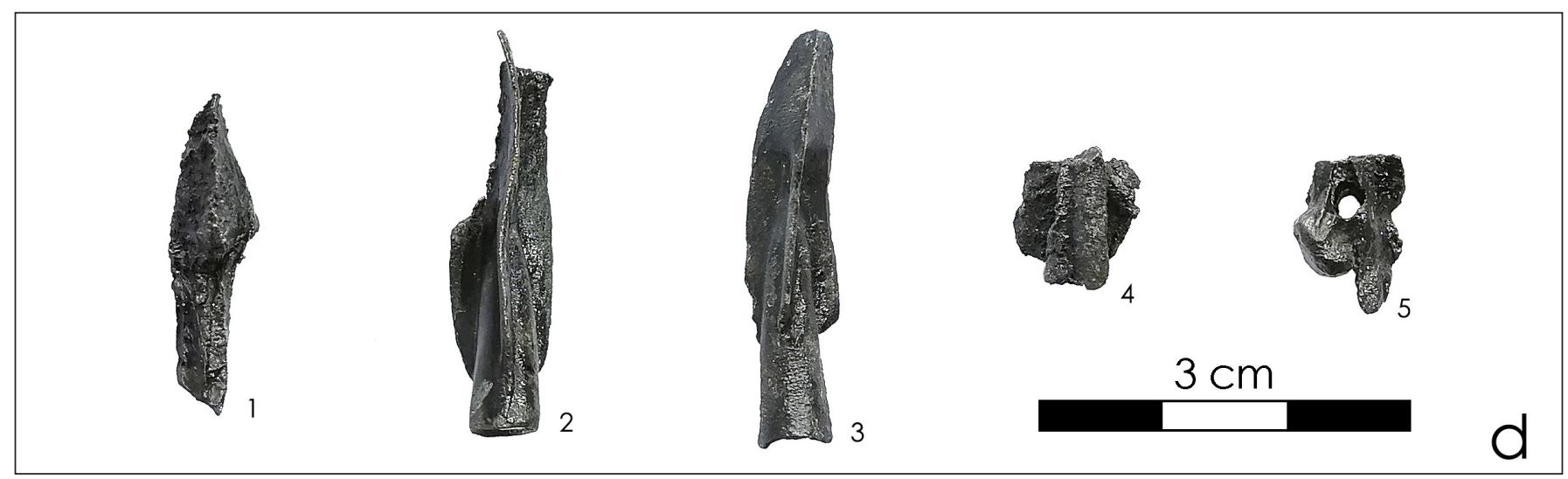

Fig. 2. Molten and damaged arrowheads from the rampart area

\section{THE METHODS AND COURSE OF THE EXPERIMENT}

The experiment was conducted in three stages. First, the replica bows and arrows were created, along with some targets made of different materials. The second phase was a test shooting performed on the site where the arrowheads were found in order to learn about the shooting ranges of the arrows and the possible posi- 
Gábor V. Szabó et al. $・$ A Shooting Experiment with Reconstructed Scythian Arrows and Bows

tions of the attackers. The third stage was an analysis of the damage on the arrowheads to determine and distinguish between the marks caused by having been fired from arrows of different strengths, from various distances, and hitting different surfaces.

\section{THE PREPARATION OF THE ARROWS}

Of the arrowhead types discovered at Verebce-tető (Fig. 3), three were chosen for the test shooting (Fig. 4): a two-edged arrowhead with hexagonal blade (type 1C in Anja Hellmuth's system ${ }^{6}$ ), a threeedged bodkin with outer socket and a thorn (type $2 \mathrm{~F}$ ), and a short, three-edged, inner socketed variant (type 2B) (Hellmuth 2010, 25-27, 81-86, 63-68). Nine copies were cast of each type in bronze with $12 \%$ tin content, using the lost wax technique. ${ }^{7}$

Some replica arrows were made about $50 \mathrm{~cm}$ long, but the majority were between 60 to $80 \mathrm{~cm}$ to facilitate their repeated use and repair. The arrows' length was reconstructed based on depictions of Scythian archers on Greek vase paintings (LuKJASHKo 2015; DARAGAN 2020a, 165-167) and data from related Scythian archaeological assemblages in the steppe region. The arrows discovered in the second burial mound at Aržan, with their length ranging between 45-65 cm, also proved to be excellent analogies (Čugonov, Parzinger \& Nagler 2010, 43, 47, Abb. 52, Taf. 25-26, 47-48; Godehardt \& SchellenberG 2010, 218).

Several arrow shaft remains are known from contemporary sites in the Eurasian steppe zone. Their material shows great diversity: birch, poplar, willow, ash, pine, and tamarisk equally appear among them (e.g., TAYLOR et al. 2021, 7, Fig. 4). As we did not find any organic material in any arrowhead in the large series collected from altogether three sites in Hungary, the arrows created for the experiment were made of pine and linden. The shafts are barreled: their body thickens from the tip in the first

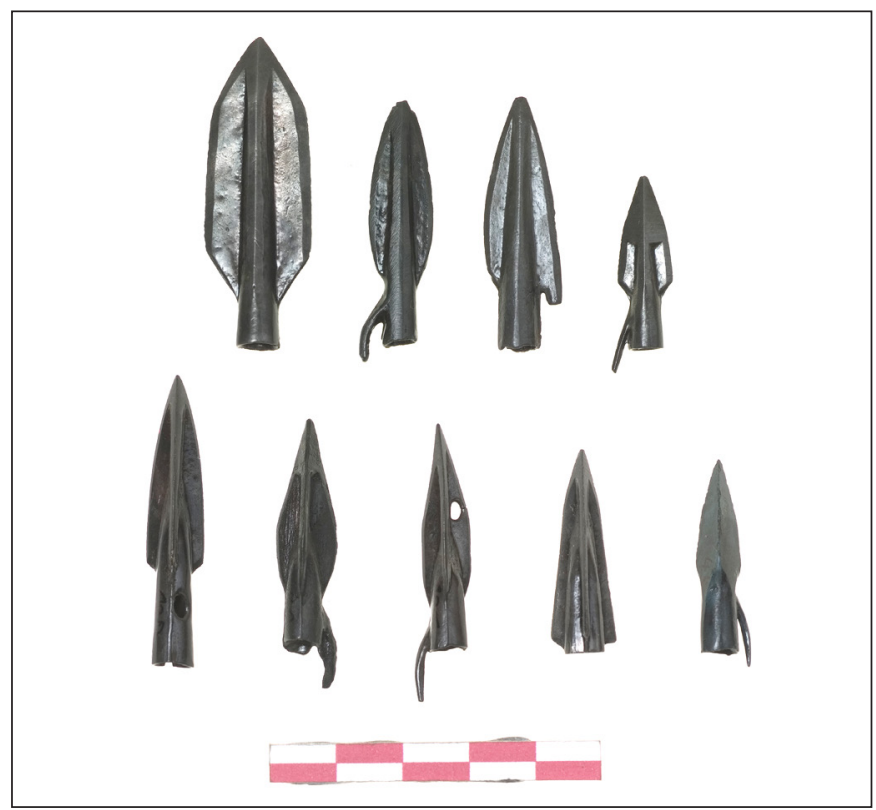

Fig. 3. Main arrowhead types from the site

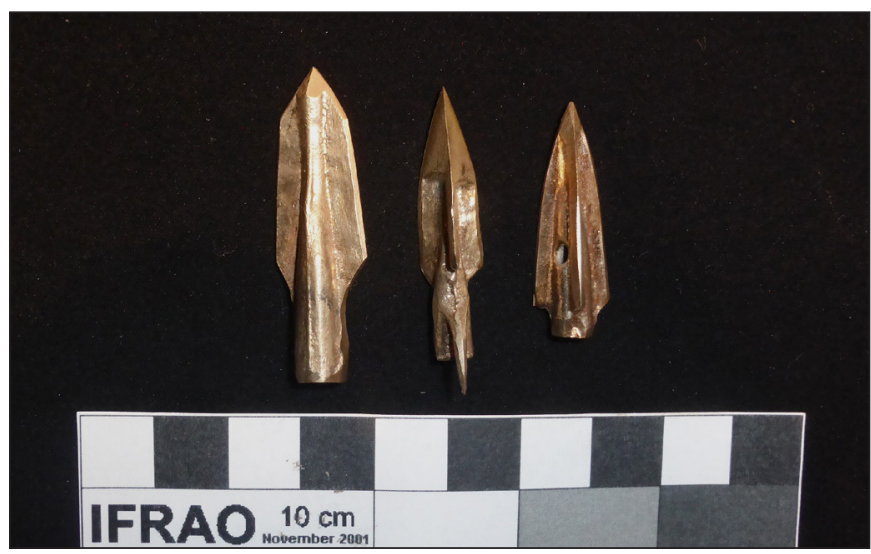

Fig. 4. Three arrowhead types chosen to be recast for the experiment two-thirds of the length, getting thinner again from there towards the nock (a vertical groove at the end of the shaft for fixing the string); finally, just before the nock, it starts to thicken again. The maximum diameter of a replica arrow shaft is $1.0 \mathrm{~cm}$, the minimum is $0.8 \mathrm{~cm}$; their weight ranges between 20 and 44 grams.

Just like Scythian arrowheads in general, the pieces found at Verebce-bérc were relatively narrow socketed. That means the wooden shaft's end must have been cut into a conic shape, thus significantly raising the possibility of breaking. To reinforce their fastening, the arrowheads were wrapped around tightly with

\footnotetext{
6 Anja Hellmuth Kramberger has outlined a typological classification for the arrowheads of eastern origin, used in the sieges in Central Europe during the Iron Age. We are using the typological and chronological categories as presented in HELLMUTH 2010 .

7 For the methods of arrowhead making see DARAGAN \& ROMANENKo 2021.
} 


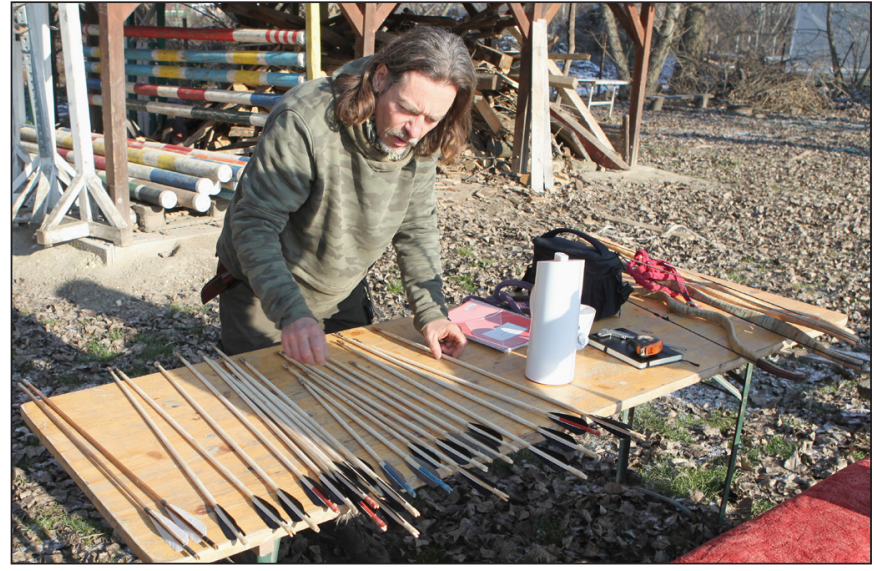

Fig. 5. Replica bows and arrows ready for the experiment

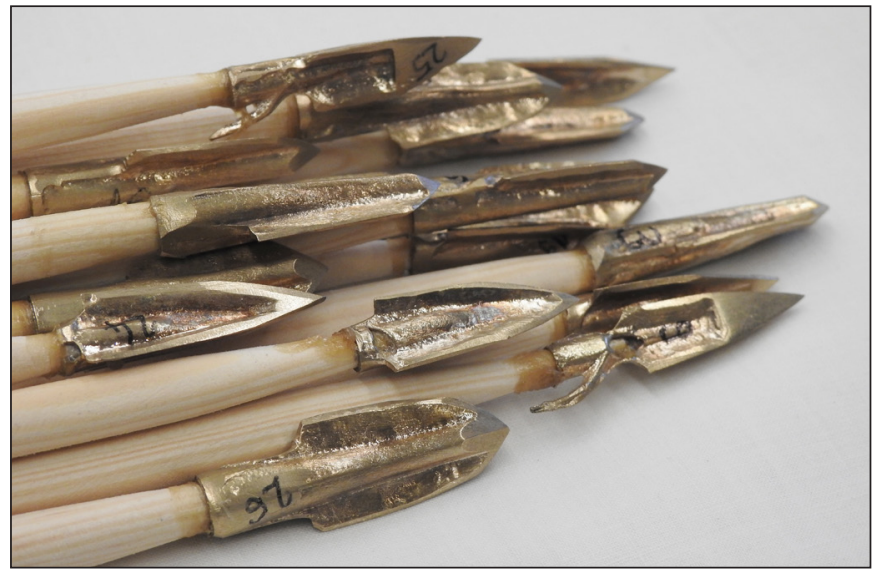

Fig. 6. Replica arrows used in the experiment

glued deer tendon at the bottom of the tip. Both ends of the fletching were also reinforced the same way. The fletching of the reconstructed arrows was made of turkey and wild goose wing quills. Altogether 27 arrows were made for the experiment.

\section{THE BOWS USED IN THE EXPERIMENT}

In the course of the experiment, shots were fired at different targets from three replica bows of different structures (Godehardt 2009; GodeHARdT-SchellenBerg 2010; LuKJashKo 2015; LuKJashKo 2016; DaraGAN 2020b) reconstructed based on archaeological findings related to the Scythians (Fig. 7). The replicas were made using exclusively traditional methods and materials: wood, horn, animal tendons, as well as hide glue and swim bladder glue for fastening.

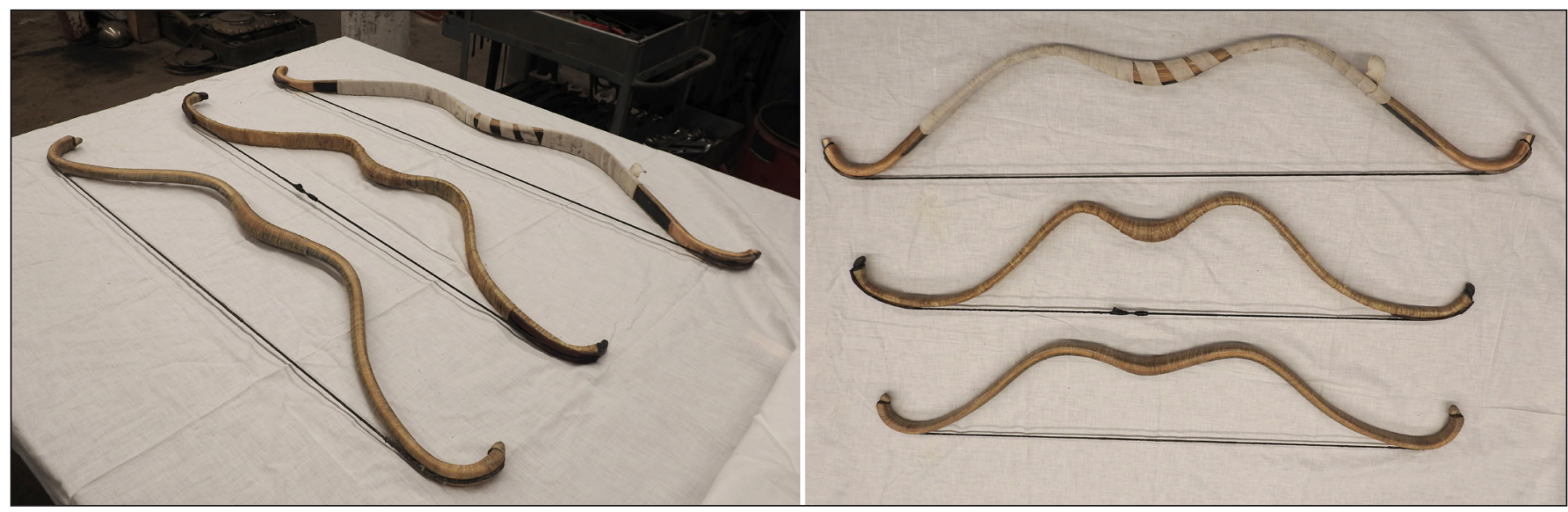

Fig. 7. Replica Scythian type bows used in the experiment

Bow no. 1 is a replica of the Vishnevka bow, one of the few Scythian bows discovered in the Northern Pontic region (ANDRUH 1988, 164-165, Ris. 4.1-2). The remains of the original have been recovered from the grave of an Early Scythian warrior. It consisted of a wooden core with glued-on horn and tendon layers, covered in birch bark. The replica was made by Attila Kiss.

Bow no. 2 is a reconstruction of a fragmented bow from the central burial (grave no. 5) in the second burial mound at Aržan. It consisted of multiple wooden layers glued together, a structure similar to the bows of the Obi-Ugors and modern laminated types (Godehardt \& Schellenberg 2010). ${ }^{8}$ Accordingly, the replica bow

8 Upon analysing the Aržan bow E. Godehardt concluded that it was a symbolic, funerary object without practical function (Godehardt et al. 2009, 32; Godehardt \& Schellenberg 2010, 218). In our opinion, it cannot be excluded that the bow was functional when it was placed in the grave, and the limbs were only missing at the time of discovery due to an advanced state of decay. 
was built of a core of multiple wooden layers glued together, with glued-on horn and tendon layers. The original version was built by Rudolf Faustmann, while later, Attila Kovács made some corrections.

Bow no. 3 is a copy of a bow dated to the 5 th -3 rd centuries BC, found in excellent condition at Subashi in Xinjiang, China (Dwyer 2003; RIESCH \& Rutschke 2009; Karpowicz \& Selby 2010). The core is made of layered steam-bent blackthorn wood and water buffalo horn stripes, fastened with sturgeon swim bladder glue; the back is reinforced by a double cattle tendon layer. The core was wrapped around tightly with animal tendons at full length for reinforcement. Finally, the whole bow was covered in waterproof birch bark stripes to protect it from humidity (KIss 2020, 954-955). This bow was made by Vilmos Pári (Fig. 8).

The bows in the experiment were of different draw weights. At a draw length of $60 \mathrm{~cm}$ (23.7 inches), the

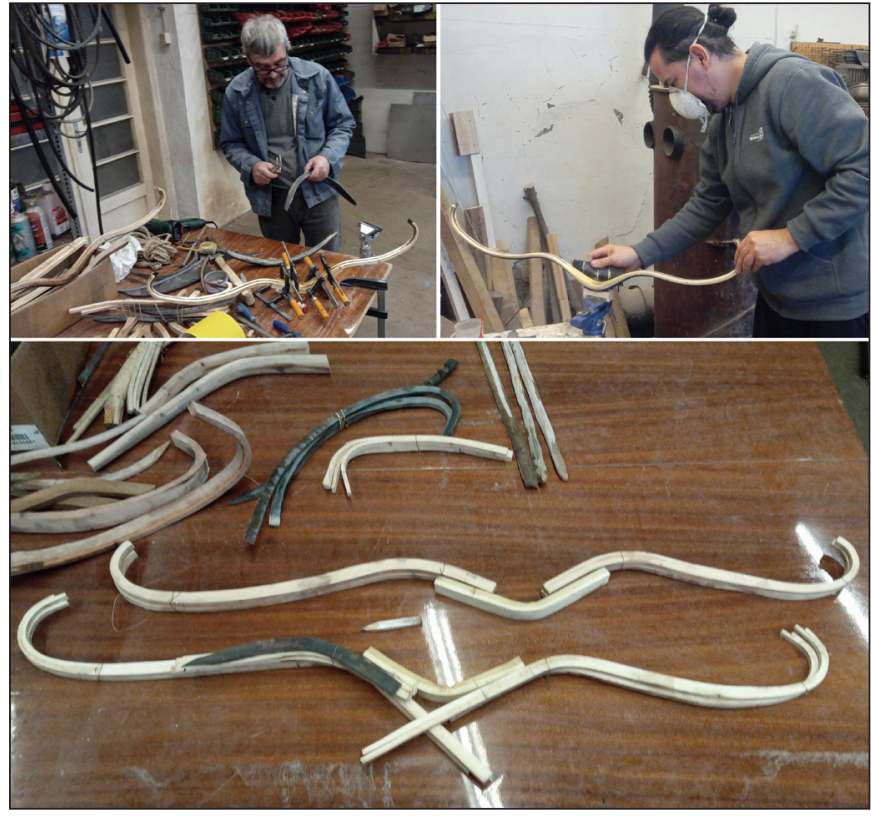

Fig. 8. Different stages of the preparation of the Scythian type replica bows used in the experiment draw weight of bow no. 1 is 55 pounds, while bow no. 2 is 72 pounds, and bow no. 3 is 101.75 pounds. Bow no. 2 broke in the course of the stress test, still on the shooting rest (at the time, the temperature was $-10^{\circ} \mathrm{C}$ ). The archer's skills must also have affected the bow's performance: Zoltán Henrik Tóth was able to draw bow no. 3 to $43.18 \mathrm{~cm}$ (17 inches), draw weight: 62.48 pounds, while Attila Kiss to approximately $53 \mathrm{~cm}$ (21 inches), draw weight: 88.44 pounds.

There are several elements of uncertainty about the reconstructed bows. The originals come from areas more to the east than the arrows, and it cannot be excluded that the attackers of the hillfort at Dédestapolcsány used different bow types. The experience gained in the shooting experiment seems to bolster this assumption: based on their draw weights, not every bow and arrow in the experiment was compatible, and it was not possible to shoot accurately with the shorter, lighter arrows. For a high shooting accuracy, the bow's strength and the arrow's weight and flexibility must be in complete accord - a condition not fulfilled in some cases.

\section{TARGET SHOOTING}

Three different targets were constructed for the experiment, each of them representing a main architectural element of Late Bronze and Early Iron Age hillfort settlements. Our goal was to learn about the damage marks on the arrowheads caused by hitting different targets, and to possibly connect damage mark types and target types, that is, to tell from the damage what had the arrow hit.

The first target was built of hardwood logs and timbers to imitate the palisade wall, while the second was woven of thick twigs to represent wattle structures. The third was a textile bag stuffed with compacted soil and stones for the earthwork's footwall and the inlay of the palisade, which comprised a timber framework with soil stamped in the gaps. The wattle target was covered by raw humid cattle skin

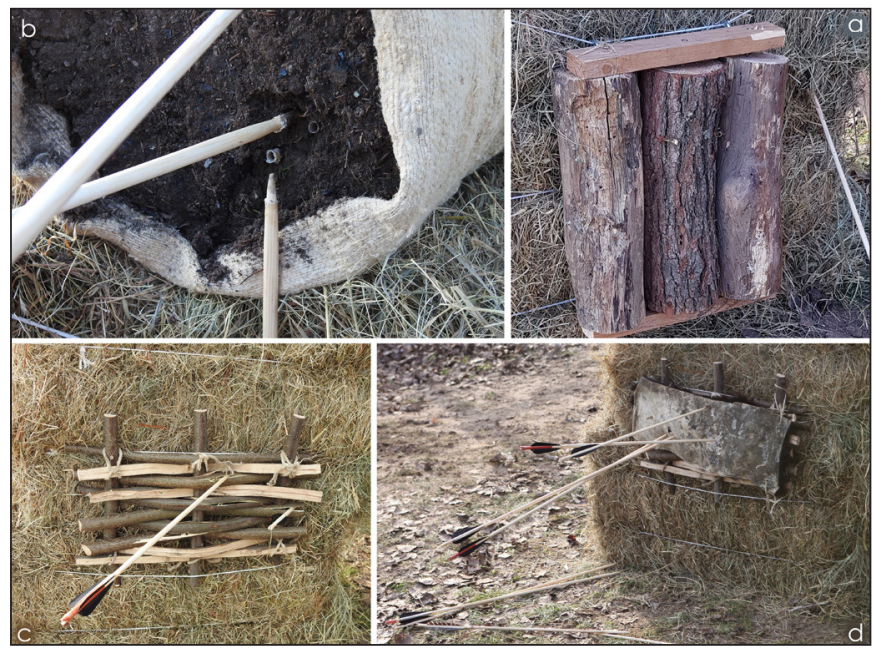

Fig. 9. Targets prepared for the experiment: a) hardwood logs to mimic palisade walls; b) compacted soil and stones; c) wattled twigs; d) wattle covered by cowhide 
Gábor V. Szabó et al. • A Shooting Experiment with Reconstructed Scythian Arrows and Bows

as the defenders probably used a similar technique to protect these surfaces from fire arrows (Fig. 9).

As our primary objective was an analysis of the damage marks on the arrowheads caused by hitting diverse targets, the arrows were fired from a relatively small distance of $8 \mathrm{~m}$. Another reason behind the small shooting distance was the above-mentioned incompatibility of some bows and arrows: fired from a distance, the arrows would simply miss the targets.

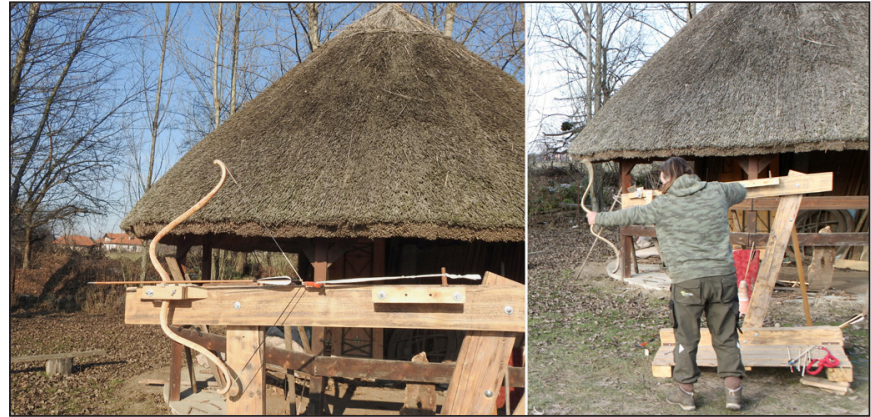

Fig. 10. Target shooting from hand and using a shooting rest

When conducting experiments with replicas of historical bows, the members of both the Magyar Történelmi Íjász Társaság (Hungarian Historical Archery Society) and the Zengö Nyil Egyesület (Hissing Arrow Organization), cooperating with us in the current project, use shooting rests for precise documentation of the shots and more accurate measuring of the bows' performance (Fig. 10). In the course of the current experiment with Scythian type bows, however, the available rests turned out to be incompatible as their gripping heads had been designed to provide a secure hold for bows with rigid limb ends and Ottoman horn bows, where the grip's sides and inner surface are more or less parallel with the string; whereas Scythian bows have a curved, bulging grip which is sometimes thicker compared to the above-mentioned historical bow types. Therefore, in the current experiment, the shots had to be fired from hand.

\section{SHOOTING EXPERIMENT ON THE SPOT}

The first shooting experiment was carried out in January 2021 at Dédestapolcsány-Verebce-tető, on the part of the site where the siege had been localized. Most of the arrows were fired from an area before the rampart section where the traces of the pristine storm of arrows had been discovered; the shots were aimed towards the fortifications. The height difference between the probable position of the attackers and the top of the ramparts must have been about 15-20 m (Fig. 11).

By that time, we have learned from previous experiments (KIss 2020, 956-958) that the maximum shooting distance of a Scythian type bow is about $130-140 \mathrm{~m}$, while the ideal shooting angle is $45^{\circ}$. In this case, it was not possible to keep with the ideal angle due to the significant height difference between the assumed positions of the attackers and the defenders (Fig. 12); therefore, the majority of the targeted shots were aimed higher. The trees in the forest also represented an obstacle in the way of the desired trajectories and, thus, the experiment.

The greatest distance covered by an arrow in the course of the shooting experiment was $110 \mathrm{~m}$, but the majority of the arrows landed at a distance between 80 to 90 metres. We have to be aware that

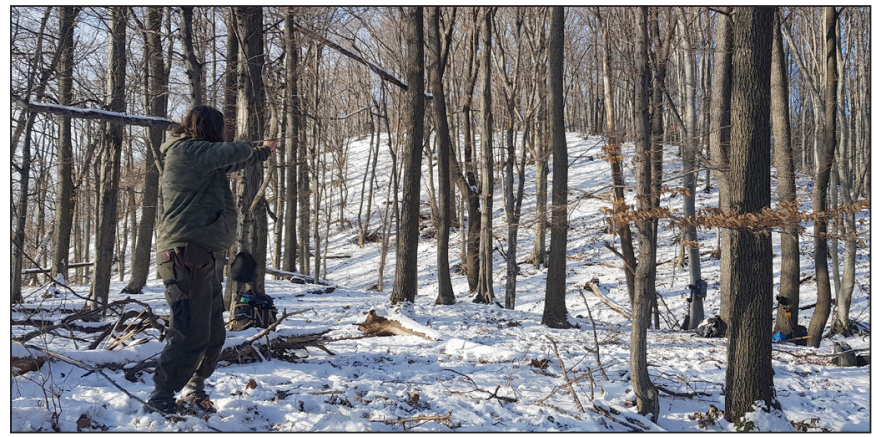

Fig. 11. Location of the on-the-spot shooting experiment in the foregrounds of the earthworks at DédestapolcsányVerebce-bérc. The shot were fired from the assumed position of the attackers towards the ramparts

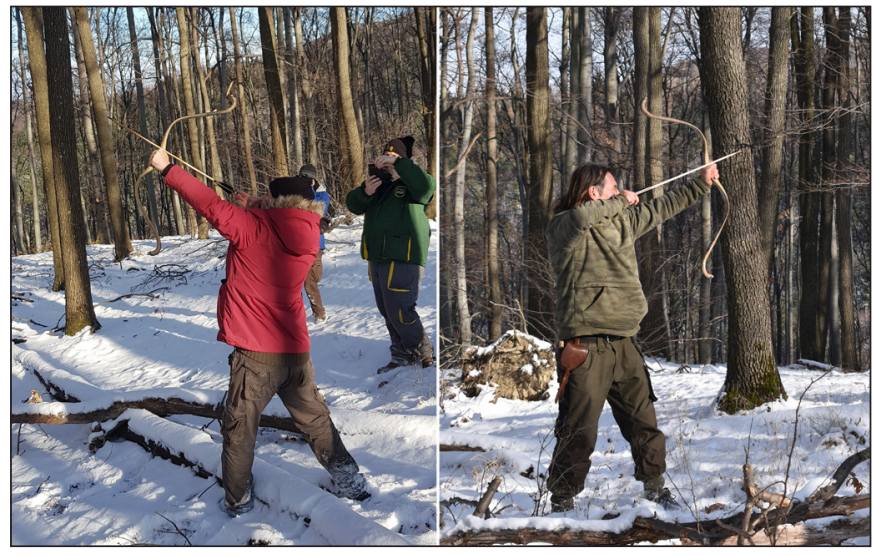

Fig. 12. Archers releasing their arrows during the on-the-spot shooting experiment 
Gábor V. Szabó et al. • A Shooting Experiment with Reconstructed Scythian Arrows and Bows

the shooting range of the attackers' bows was probably considerably larger due to their experience ${ }^{9}$ and the compatibility of their bows and arrows.

At the time of the experiment, the temperature was $-15^{\circ} \mathrm{C}$, which perhaps also affected the working of the bows and the arrows.

\section{RESULTS OF THE EXPERIMENT: NEW DATA ON THE HISTORY OF THE SIEGE}

The experiment has provided us with the following results:

The experimental shots fired on the spot, from the assumed positions of the attackers towards the palisade wall, proved that during the siege, the shots targeted behind those walls landed at a distance of a hundred metres or less. This result suggests that the arrowheads discovered in the inner parts of the Early Iron Age hillfort, 150 to 400 metres away from the defensive earthworks, did not arrive there by having been fired from outside the settlement but mark the success of the attackers who managed to get through the walls and attack from inside the houses.

Some molten everyday bronze objects found by metal detector aided surveys in settlement parts near the earthworks might also be interpreted as marks of the attackers' assumed success. There are similar phenomena in the archaeological record of Smolenice-Molpír, a settlement destroyed by a single catastrophic event involving a vast fire (MÜLLER 2012, 248-250; Hellmuth 2017, 571-575).

Some arrows hitting the post wall structure of the palisade bounced off, and almost every piece broke upon impact. One of the bounced-off arrows flew back as much as 5 metres, while many of the impacted ones penetrated the oaken posts as deep as 1.5 to $2 \mathrm{~cm}$ (Fig. 13). Only one of these was successfully retrieved, and the arrowhead showed no damage (Fig. 14).

When covered with cattle skin, the wattle has also proven to be successful in capturing the shots; but without a cover, it was pretty ineffective, and type $2 \mathrm{~F}$ arrowheads could even break through it. Damage was only visible in one case: the tip of a type $2 \mathrm{~B}$ arrowhead became chipped.

The arrowheads suffered the greatest damage upon impacting the compacted soil-and-stone target. Some of them penetrated the soil as deep as $21 \mathrm{~cm}$, but a couple of millimeters broke off the tip of the two-edged ones, while the tip of a type $2 \mathrm{~F}$ arrowhead became

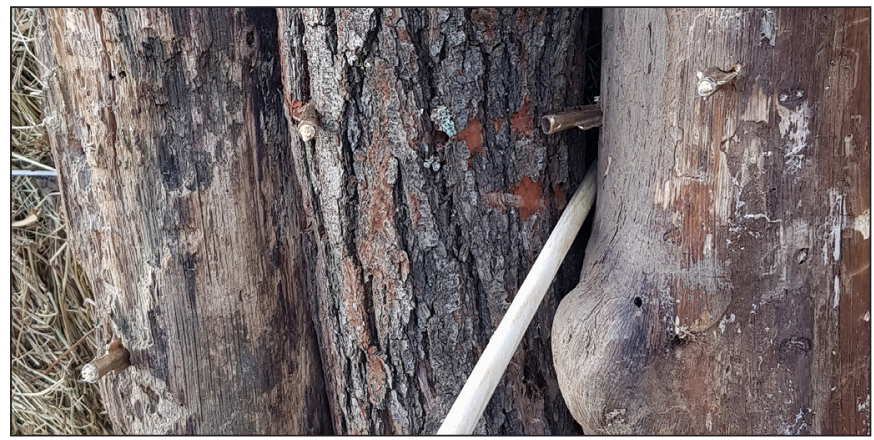

Fig. 13. Broken arrowheads that had hit hardwood logs

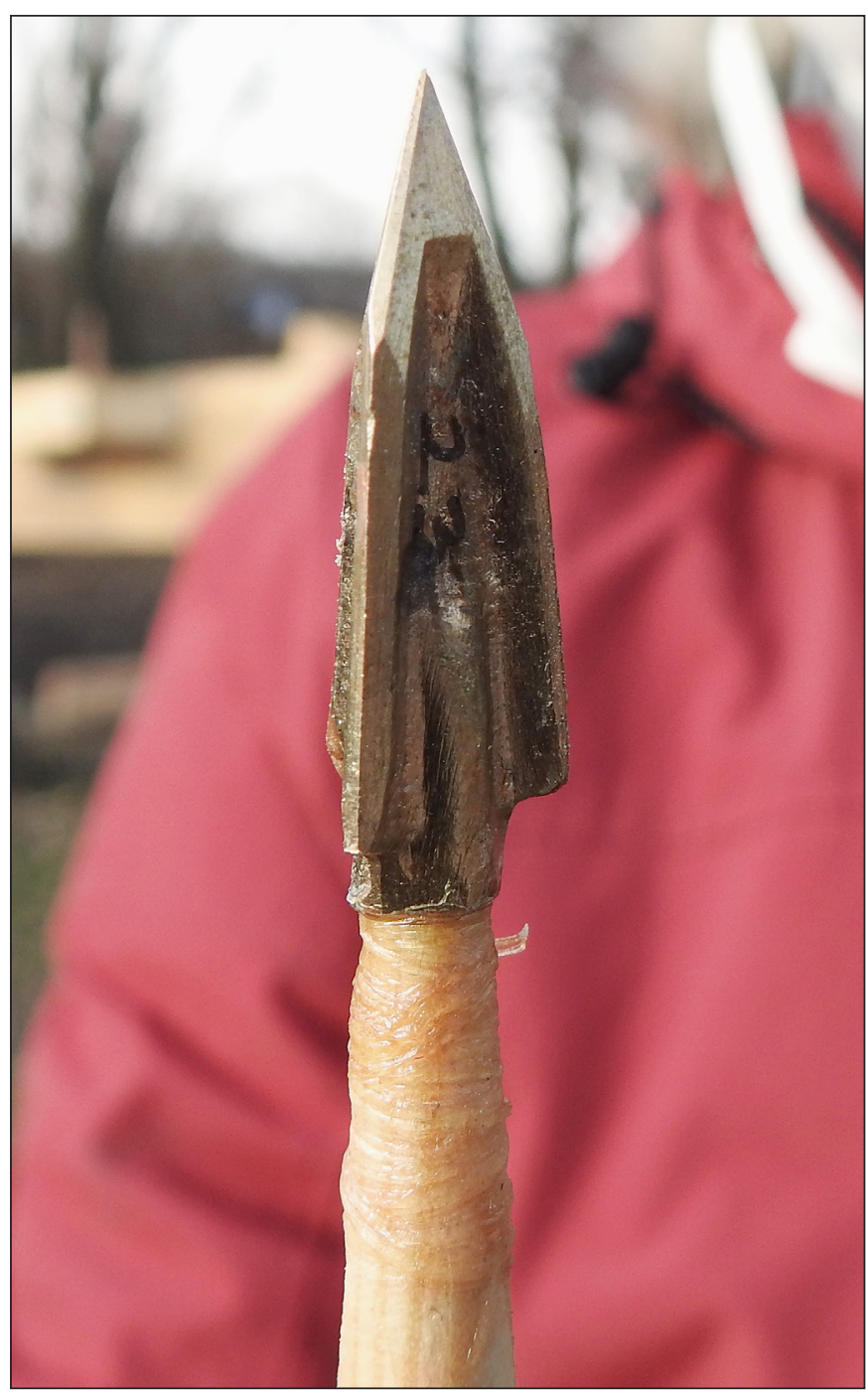

Fig. 14. Undamaged arrowhead that had hit a hardwood log

9 According to an inscription from Olbia, Anaxagoras, son of Dimagoras shot an arrow with a Scythian bow to a distance of 282 orgyai (approx. 500 metres) (BAKAS 2014; CUNLIFFE 2019, 239). 
Gábor V. Szabó et al. • A Shooting Experiment with Reconstructed Scythian Arrows and Bows

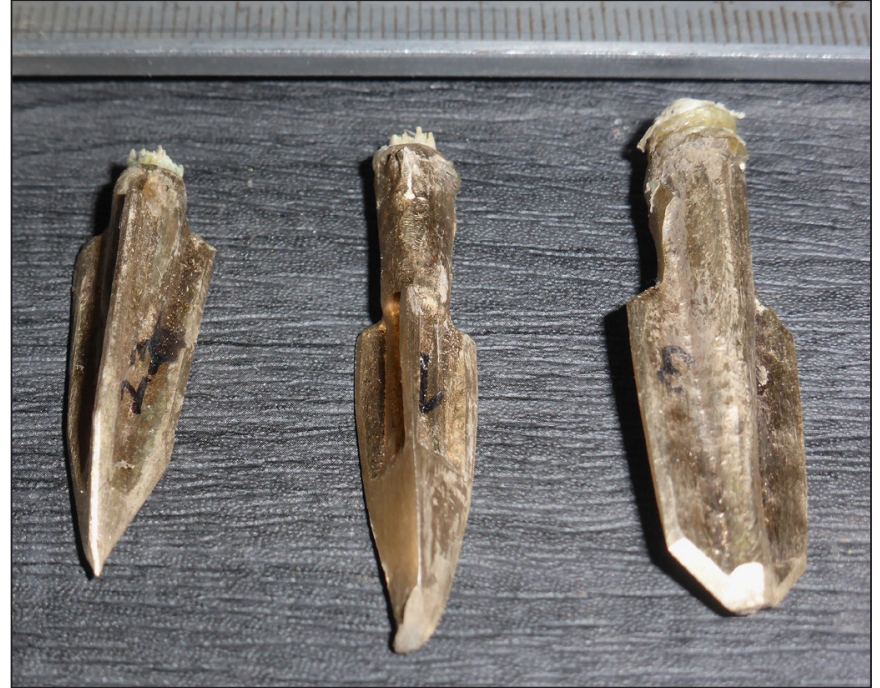

Fig. 15. Damaged arrowheads that had hit the compacted soil-and-stone target

possible for the attackers to collect the bouncedoff and broken arrows either. Furthermore, many arrows must have been stuck in the palisade wall's posts, while the ones bouncing off from there must have fallen into the moat.

The research presented in this paper is by no means complete. We plan to conduct a number of similar experiments using shorter arrow types, characteristic to the region, with replicas made of authentic wood species known from related archaeological assemblages. One of our primary goals is to adjust the bows' strength and the arrow types and analyse the damage on the arrowheads when the arrows cover larger distances like the original ones did in the course of the attack. ${ }^{10}$ highly bent when the arrow hit a stone (Fig. 15). The head broke off at the end of the socket with most of the arrows, while in some cases, the shaft simply released the head (Fig. 16). Upon extracting the arrows that had hit the soil, most of the arrowheads penetrating that remained stuck, even if the arrow had previously remained undamaged on impact. The small shooting distance was probably also a factor advancing the breaking of the arrows: due to the archer's paradox, the arrows have an oscillating motion in the air and hit the ground a little bit askew.

The test shots suggest that it was probably not an option for the archers to collect and reuse most of their arrows during the siege. The largest loss of arrows must have been suffered at the compacted soil-and-stone earthworks, but it was probably not

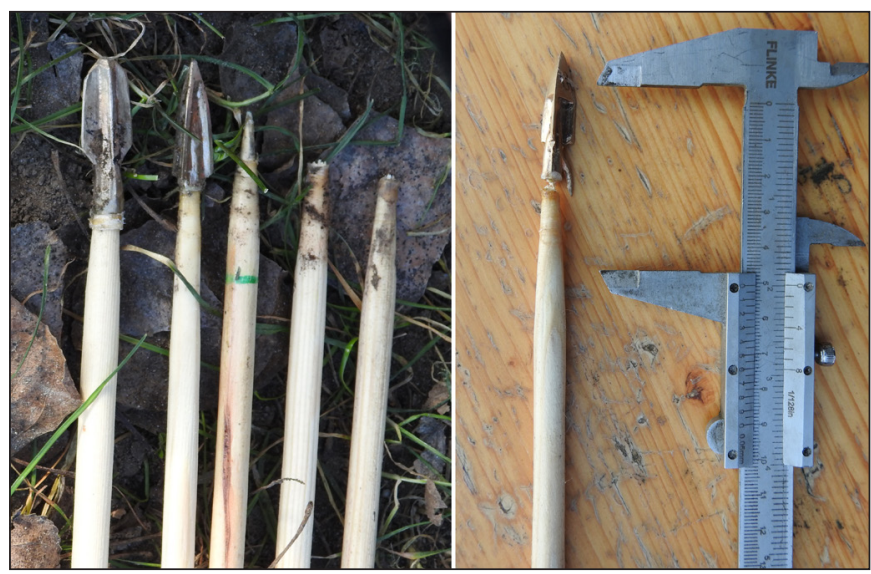

Fig. 16. Damaged arrows that had hit hardwood logs and bounced off

\section{REFERENCES}

Andruh, S. I. [Андрух, С. И.] (1988). Pogrebenie ranneskifskogo voina v Prisivash'е. [Погребение раннескифского воина в Присивашье]. Sovetskaja arheologija 1 (1988), 159-170.

Bakas, S. (2013). Anaxagoras from Pontic Olbia. The first long-distance archery achievement recorded in history. https://koryvantes.blogspot.com/2013/06/anaxagoras-from-pontic-olbia-first-long.html Last accessed: 15 August 2021.

Chochorowski, J. (2014). Scytowie a Europa Środkowa - historyczna interpretacja archeologicznej rzeczywistości / Die Skythen und Mitteleuropa - historische Deutung der archäologischen Wirklichkeit. Materiały i Sprawozdania Rzeszowskiego Ośrodka Archeologicznego XXXV (2014), 9-58.

Cunliffe, B. (2019). The Scythians: Nomad Warriors of the Steppe. Oxford: OUP.

${ }_{10}$ The research was subsidized by the National Research, Development and Innovation Office (project ID: 138768). 
Gábor V. Szabó et al. $・$ A Shooting Experiment with Reconstructed Scythian Arrows and Bows

Čugonov, K., Parzinger, H. \& Nagler, A. (2010). Die Gräber und ihre Funde. In K. Čugonov, H. Parzinger \& A. Nagler (Hrsg.), Der skythenzeitliche Fürstengrab Aržan in Tuva (pp. 217-231). Archäologie in Eurasien Bd. 26, Steppenvölker Eurasiens 3. Mainz: von Zabern.

Daragan, M. N. (2020a). Scythian leather quiver from Bulgakovo. Ancient Civilizations from Scythia to Siberia 26 (2020), 146-171. https://doi.org/10.1163/15700577-12341361

Daragan, M. N. (2020b). Scythian archers of the 4th century BC: A new archaeological study of excavated bows, arrowsand quivers from the northern Black Sea region. In S. Pankova \& St. J. Simpson (eds), Masters of the Steppe: The Impact of the Scythians and Later Nomad Societies of Eurasia (pp. 103-124). Oxford: Archaeopress. https://doi.org/10.2307/j.ctv1fcf8hh.14

Daragan, M. N. \& Romanenko, Y. N. (2021). Technique and technology of Scythian bronze arrowhead casting: Experimental and metallographic approach. Journal of Archaeological Science: Reports 37 (2021), 102919. https://doi.org/10.1016/j.jasrep.2021.102919

Dweyr, B. (2003). Schythian-style bows discovered in Xinjiang. Journal of the Society of Archer Antiquaries 48 (2003), 71-82.

Godehardt, D., Godehardt, E. \& Schellenberg, H. M. (2009). Der skytische Bogen. In V. Alles (Hrsg.), Reflexbogen - Geschichte und Herstellung (pp. 26-59). Ludwigshafen.

Godehardt, E. \& Schellenberg, H. M. (2010). Der Bogenfund aus Grab 5 und Überlegungen zu skythenzeitlchen Bögen. In K. Čugonov, H. Parzinger \& A. Nagler(Hrsg.), Der skythenzeitliche Fürstengrab Aržan in Tuva (pp. 217-231). Archäologie in Eurasien 26, Steppenvölker Eurasiens 3. Mainz: von Zabern.

Hellmuth, A. (2010). Bogenschützen des Pontischen Raumes in der Älteren Eisenzeit. Typologische Gliederung, Verbreitung und Chronologie der skythischen Pfeilspitzen. Universitätsforschungen zur prähistorischen Archäologie 177. Bonn: Habelt.

Hellmuth-Kranberger, A. (2017). Archäologische Hinweise zu kriegerischen Auseinandersetzungen mit reiternomadischen Gruppen im östlichen Mitteleuropa und im Vorderen Orient. In E. Miroššayová, C. Pare \& S. Stegmann-Rajtár (Hrsg.), Das nördliche Karpathenbecken in der Hallstattzeit: Wirtschaft, Handel und Kommunikation in früheisenzeitlichen Gesellschaften zwischen Ostalpen und Westpannonien (pp. 571589). Budapest: Archaeolingua.

Karpowicz, A. \& Selby, S. (2010). Scythian bow from Xinjang. Journal of the Society of Archer Antiquaries 53 (2010), 94-102.

Kiss A. (2020). „Ijuk, mint isten karja, és nyilaik elől nincs menekvés.” Sztyeppei típusú szaru-ín összetett íjak és nyílvesszők használati értékének vizsgálata. - "Their bow like God's arm, no escape from their arrows". The examination of the value in use of steppe-type horn-tendon bows and arrows. Hadtörténelmi Közlemények 133/4 (2020), 953-997.

Klápa, O. (2017). "Schythian” findings in the Moravia. Acta Archaeologica Carpathica 52 (2017) 65-82.

Lukjashko, S. I. [Лукьяшко С. И.] (2015). Scythicus acrus. Strelkovoje oruzhije skifov 1. [Стрелковое оружие скифов 1.] Nauka Juga Rossii (Vestnik Juzhnovo Nauchnovo Centra) 11/4 (2015), 87-92. 
Gábor V. Szabó et al. $・$ A Shooting Experiment with Reconstructed Scythian Arrows and Bows

Lukjashko, S. I. [Лукьяшко С. И.] (2016). Scythicus acrus. Strelkovoje oruzhije skifov 2. [Стрелковое оружие скифов 2.] Nauka Juga Rossii (Vesztnyik Juzsnovo Naucsnovo Centra) 12/1 (2016), 84-92.

Müller, S. (2012). Smolenice-Molpír, Sered' und Ratkovce: Studien zu Siedlungen der frühen Eisenzeit in der Südwestslowakei. Universitätsforschungen zur Prähistorischen Archäologie 220. Bonn: Habelt.

Novák, M. (2017). Moravsky „Molpír“? Halštatske nalezy z opevněneho vyšinneho sidliště ProvodovLudkovice „Rysov“ (okr. Zlin). - Moravian “Molpír”? Hallstatt period finds from fortified hilltop settlement Provodov-Ludkovice "Rysov" (Zlín District). Pravěk Nova řada 25, (2017) 185-228.

Riesch, H. \& Rutschke, J. (2009). Der Subexi-Bogen in der Ausstellung „Ursprünge der Seidenstraße“. In V. Alles (Hrsg.), Reflexbogen - Geschichte und Herstellung (pp. 60-69). Ludwigshafen.

V. Szabó, G. (2018). Nyílzáporban. Egy kora vaskori hadjárat emlékei a Kárpát-medencében. Határtalan Régészet - Archeológiai Magazin 3 (1), 58-62.

V. Szabó, G., Czajlik, Z. \& Reményi, L. (2014). Traces of an Iron Age armed conflict. New topographical results from the research into Verebce-bérc at Dédestapolcsány I. Hungarian Archaeology 3/1 [2014 Spring], 1-6.

Taylor, W., Hart, I., Pan, C., Bayarsaikhan, J., Murdoch, J., Caspari, G. et al. (2021). High altitude hunting, climate change, and pastoral resilience in eastern Eurasia. Scientific Reports 11 (14287). https://doi. org/10.1038/s41598-021-93765-w 